\title{
UNARTICULATED DESPAIR OF MALE ACID ATTACK VICTIMS; A CRITICAL ANALYSIS
}

\author{
Ms. Ipsita Ojal \\ PhD Research Scholar (Law), Lovely Professional University, Phagwara, Punjab. \\ Dr. Varinder Kaur \\ Assistant Professor, School of Law, Lovely Professional University, Phagwara, Punjab.
}

\begin{abstract}
It is my earnest effort to put forth in this paper the spiraling acid attack cases against men which is generally and largely under estimated. The majority of acid attack victims being young women who had to face the rage of spurned lovers points out that acid attack is a gender-based violence. But the horrific stories of male acid victims are not discussed despite the considerable share of acid attack victims being men. This article aims to delve into and deliberate the abuse and assault faced by men in the form of acid attack, which is not much spoken to about.
\end{abstract}

\section{KEYWORDS: Acid Attack, Acid Victims, Burn Victims}

\section{INTRODUCTION}

The diabolic method of acid attack to wreck vengeance against human beings who become the subject of hatred and the prime intention of the assailant would be to disfigure or maim the victim especially on the upper part of the body and the main target being the face of the victim, the victim may go disabled and, in some cases, even it would result in fatality. The assailant knows that the said act is likely to cause such disablement which would render the victim automatically ostracised from family, society as well as work place, thus depriving the victim from leading a normal life and driving the victim to a corner which would give sadistic pleasure to the assailant. The acid even ends up melting the skin, flesh and bones.

Predominantly in India acid attacks take place against women yet it is estimated by the NCRB that more than 30 to 40 percent acid attack victims are men. ${ }^{1}$ It is mainly economic or land disputes, revenge and hate that culminates into acid attack. Victims being men and such commissions of offenses is perpetrated by the cheap and easy availability of acid like sulfuric acid nitric acid or hydrochloric acid generally and hence multi-pronged strategy requires to learn about the root cause to resolve the issue. Acid attacks were widespread in the UK, France, and several European countries since the 18th century. Nowadays acid attack goes on spiralling involving South East Asia, South Asia, Central and North Africa mostly. Most of the attacks do not kill the victims but attacks cause serious disfigurement, leading the victim to lead an isolated life without socializing, ultimately leading to economic downfall, poverty and depression.

\footnotetext{
${ }^{1}$ Retrieved from: https://www.indiatoday.in/mail-today/story/supreme-court-to-look-into-male-acid-attackvictims-woes-1166957-2018-02-11 (Last accessed on 5th February 2022 at 10.20hrs)
} 
The general perception prevails in the society is that women are only victims of acid attacks but the supreme court gave guidelines in 2013, that prescribed all the victims compensation but most of the state governments respected the compensation only for women victims. There is discrimination, deep rooted in the issue of granting compensation and women victims get the same quickly while those male victims do not many times get the compensation. The number of male victims compared to women is less. When the question of compensation comes the rules are not much in favour of men, causing great resentment among men and the NGOs and other organizations and institutions are not much interested in projecting the pain of men victims.

\section{INTERNATIONAL HISTORY OF ACID ATTACKS}

The history of acid traces back to the Greek where physician Dioscorides in $1^{\text {st }}$ Century AD noted vitriol was utilized in gold and precious metal making so as to purify it. From the $2^{\text {nd }}$ Century AD, it is even noted that Romans, Indians, Arabs, Persians, Sumerians also used vitriol. $^{2}$

The Industrial revolution brought new manufacturing techniques and changed the production process into a machine dominated economy. ${ }^{3}$ During the period of Industrial Revolution starting from the late 1700 's the use of acid became widely popular for various purposes such as bleaching, polishing, purification, jewellery making, fertilizer making, cleansing, paint production etc., and therefore acid became easily accessible and available in markets. ${ }^{4}$ Sulphuric acid was even regarded as the backbone of Industrial Revolution because of its diverse use ${ }^{5}$

During this period many acid attacks were reported. In Europe acid violence was reported during the $16^{\text {th }}$ Century and in France in the $17^{\text {th }}$ Century during the rule of Louis XIV. Umpteen reports point that in the United Kingdom and Europe during the $19^{\text {th }}$ Century acid attacks became prevalent. In France in the year 1879 as high as 16 acid attacks were reported and during the period of 1888 to 1890 the number of acid attacks skyrocketed to $83 .{ }^{6}$

\section{LEGAL FRAMEWORK FOR ACID ATTACKS IN INDIA}

\section{Legal Framework Under the Indian Constitution}

When viewed through the Constitutional prism the Constitution of India aims for achieving sublime and lofty social philosophy by alleviating the poverty and miseries of masses and inventing checks and balances between individual rights and social harmony. The basic human rights and freedom is provided in Articles commencing from 12 to 35 in Part III of the Indian

\footnotetext{
2 Karpenko, V. and Norris, J.A, "Vitriol in the History of Chemistry" 96 Chemicke Listy 997-1005 (2002).

${ }^{3}$ Britannica, Industrial Revolution, available at https://www.britannica.com/event/Industrial-Revolution (last visited on 11th Spetember 2021).

${ }^{4}$ Aplus Topper, Uses of Acids, available at https://www.aplustopper.com/uses-of-acids/ (last visited on $11^{\text {th }}$ September 2021).

${ }^{5}$ Kragh and H Stjernholm, "Sulphuric acid was the bedrock of the Industrial Revolution And it is still used in fertilisers the world over today", Science Nordic (2017), available at http://sciencenordic.com/sulphuric-acid-was-bedrockindustrial-revolution (last visited on $11^{\text {th }}$ September 2021).

${ }^{6}$ Jane Welsh, "It was Like Burning in Hell": A Comparative Exploration of Acid Attack Violence (2009)

(Unpublished Thesis, University of North Carolina at Chapel Hill).
} 
Constitution, which provides for equal protection of laws, freedom of speech and expression, freedom of worship and religion, freedom of association and assembly, freedom to settle anywhere in India, freedom to move anywhere, free to choose occupation, trade or business etc.

Out of these the most important is Article 21 of the Indian Constitution which guarantees personal liberty and personal liberty shall be restricted by procedure established by law alone. It ensures that the following traits are inseparable from human beings: -

1. Every human has emotions and ambitions

2. Every human being is a creation of nature

3. Every human has reason and vision.

4. Every human has natural rights.

5. Every human has the capacity to exercise rights.

6. Every human being has the right to dignified life.

7. Every human shall have the fullest opportunity to develop their personality.

These rights and freedom could be deprived only by procedure established by law, or in other words by due process of law. In India procedure established by law could be civil procedure code and criminal procedure code that apart, equity, good conscience, natural justice etc also would be applicable in matters established by law. So, whenever the question of law with respect to matters involving women comes up Article 21 along with equity, good conscience, natural justice etc would be the criterion for deciding the issues.

\section{Legal Provisions Under the Indian Penal Code}

Under the Indian Penal Code there were no specific sections for acid attack till 2013 and sections such as sec. $319^{7}$, sec. $320^{8}$, sec. $321^{9}$, sec. $322^{10}$, sec. $324^{11}$, sec. $326^{12}$ etc. were charged against perpetrators. Later a Public interest Litigation filed by a victim named Laxmi brought changes in both the Indian Penal Code and in the Code of Criminal Procedure. In the Indian Penal Code sec. $326 \mathrm{~A}^{13}$ and sec. $326 \mathrm{~B}^{14}$ were introduced specifically in order to address acid crimes which are alarmingly increasing in India.

\section{Legal Provisions Under the Criminal Procedure Code}

In the Code of Criminal Procedure sec.357A, sec. 357B, sec. 357C were inserted with the aim of providing compensation to victims. The section 357A mentions about the Victim Compensation Scheme while section 357B points that compensation has to be paid in addition to fine under the section 326A of IPC. Section 357C elaborates about the treatment of victims and this section describes that both the private as well as public hospitals managed by the

\footnotetext{
7 The Indian Penal Code, 1860 (Act 45 of 1860), sec.319- Hurt.

8 The Indian Penal Code, 1860 (Act 45 of 1860), sec.320- Grievous Hurt.

${ }^{9}$ The Indian Penal Code, 1860 (Act 45 of 1860), sec.321- Voluntarily causing hurt.

${ }^{10}$ The Indian Penal Code, 1860 (Act 45 of 1860), sec.322- Voluntarily causing grievous hurt

${ }^{11}$ The Indian Penal Code, 1860 (Act 45 of 1860), sec.324- Voluntarily causing hurt by dangerous weapons or means.

${ }^{12}$ The Indian Penal Code, 1860 (Act 45 of 1860), sec.326- Voluntarily causing grievous hurt by dangerous weapons or means.

${ }^{13}$ The Indian Penal Code, 1860 (Act 45 of 1860), sec.326A- Voluntarily causing grievous hurt by use of acid, etc.

${ }^{14}$ The Indian Penal Code, 1860 (Act 45 of 1860), sec.326B- Voluntarily throwing or attempting to throw acid.
} 
Central Government, State government or any other government body should provide first aid and medical treatment freely to victims who are covered under section 326A, sec 376, sec 376A, sec 376B, sec 376C, sec 376D or sec 376E of the Indian Penal Code.

\section{SCHEMES FOR ACID ATTACK VICTIMS IN INDIA}

\section{a.) Nirbaya Fund}

The Nirbaya Fund was established by the Indian government to improve the protection and safety of women in India. Proposals for funding under the Nirbaya Fund are evaluated and recommended by an empowered committee of officers. One Stop Centre Scheme is implemented throughout the country since April 2015. Women affected by violence are provided integrated service under one roof, wherein police aid, medical aid, legal aid, psychosocial counselling and temporary shelter. More than 700 one stop centres are being operated and above 3 lakh women have been assisted through.

\section{b.) One Stop Centre Scheme}

One Stop Centre's were introduced with the motive of supporting female victims exposed to violence. Those women who are abused physically, sexually, emotionally, psychologically or economically irrespective of age, class, caste, marital status, race and culture will be facilitated with support and redressal.

Women who have been subjected to sexual assault, domestic violence, trafficking, honor related crimes, acid attack or witch hunting will be provided with special treatment and services once they reach or are referred to One Stop Centre.

The target group of One Stop Centre include all women and even girls below 18 years of age who were victims of crime irrespective of caste, class, religion, sexual orientation or marital status. For minor girls Juvenile Justice (Care and Protection of Children) Act, 2000 will apply and institutions and authorities established under such Act will be linked with the One Stop Centre.

The services provided in One Stop Centre's are as follows: -

1. Emergency Response and Rescue Services.

2. Medical Assistance.

3. Assistance to women in lodging FIR/ NCR/ DIR.

4. Psycho-social counselling.

5. Legal aid and counselling.

6. Shelter.

7. Video Conferencing Facility.

\section{REASONS RESULTING IN ACID ATTACKS}

There are a variety of causes which result in acid attacks. The most common reasons are rejected romance, family conflicts, dowry demands, denial of sexual favor, gang based disputes, politically motivated problems, business rivalry and land disputes. 


\section{A. Rejected Romance}

Romantic involvement between two persons most often male and female and in rare cases it could be emotional involvement between same sex individuals, when the initial warmth is lost it could lead to jilting of partner ${ }^{15}$ which invariably leads to great frustration and embarrassment and even hatred and may culminate into revengeful thoughts and game plan to victimize the partner wherein various methods are adopted out of which one of the horrific and dastardly act is acid attack so as to ruin the partner by disfiguring the mortal frame, thereby persecuting the partner psychologically also. ${ }^{1617}$

\section{B. Family Conflicts}

Instances of family feud on account of ancestral share in immovable property had a tendency to create rift among the family members where some members due to avarice dreams of pocketing bigger proportion in the share, but when faced with challenge by some other family member, the bitter feelings would emanate to eliminate such rivals or else victimize the rivals by physical attacks wherein acid also plays a distinct role, the substance of attack being corrosive could cause significant damage to the physical frame, the perpetrator entertaining the wishful thought of liquidating or debilitating the victim, thereby the victim may not pose a threat for the evil designs of the perpetrator. ${ }^{18}$

\section{Dowry Demands}

Another reason for acid attack is the prohibited demand for dowry. These instances and such atrocities are mainly found in countries like India ${ }^{19}$, Bangladesh, Pakistan etc., where the evils of illegal demand for dowry remains deep rooted, the societies being mostly conventional, traditional and conservative, as this evil was there for a few centuries. During the process of marriage and during the post marital life also, the demand for dowry in the form of gold and silver jewelry, household articles like furniture, electrical and electronic goods etc. are frequently demanded by the bride's in-laws and the demand is not met as a pressurizing tactic, the in laws including the husband perpetrates violent methods to get possession of such valuables including liquid currency and this on several occasions culminated in acid attack ${ }^{20}$, the unconscionable act wherein the victims were always the hapless brides. ${ }^{21}$

\footnotetext{
${ }^{15}$ Retrieved from: https://imesofindia.indiatimes.com/city/bhubaneswar/rejected-in-love-man-throws-acidon-kalahandi-girl/articleshow/62521878.cms (Last accessed on 13th January 2022 at 20.31hrs)

${ }^{16}$ Retrieved from: https://www.thehindu.com/news/national/other-states/jilted-love-the-cause-of-acidattack-report/article6409665.ece (Last accessed on 15th January 2022 at 15.20hrs)

${ }^{17}$ Retrieved from: https://www.dailyo.in/lifestyle/toxic-masculinity-kabir-singh-acid-attack-love-rejectionspoilt-indian-men/story/1/31322.html (Last accessed on 15th January 2022 at 22.20hrs)

${ }^{18}$ Retrieved from: https://www.newindianexpress.com/cities/hyderabad/2018/aug/04/financial-disputewith-kin-led-to-acid-attack-1852985.html (Last accessed on 13th January 2022 at $14.11 \mathrm{hrs}$ )

${ }^{19}$ Retrieved from: https://www.dailyo.in/variety/woman-acid-attack-dowry-triple-talaq/story/1/16784.html (Last accessed on 15th January 2022 at $20.11 \mathrm{hrs}$ )

${ }^{20}$ Retrieved from: https://timesofindia.indiatimes.com/city/bareilly/woman-dies-after-in-laws-pour-acidinto-her-mouth-for-not-fulfilling-dowry-demand/articleshow/70665662.cms (Last accessed on 15th January 2022 at $20.15 \mathrm{hrs})$

${ }^{21}$ Retrieved from: https://www.newindianexpress.com/states/odisha/2017/jun/14/acid-attack-over-dowrydemand-1616445.html (Last accessed on 13th January 2022 at 19.17hrs)
} 


\section{Denial Of Sexual Favour}

Yet another reason for acid attack against women is the rebuffing of sexual favors solicited by boys and men which unveils the male chauvinism wherein members of masculine gender harbors the notion of dominion over female body and when the rejection by women may trigger the opposite sex to avenge for the humiliation faced by men. In such instances especially in countries like Bangladesh, India and other South-Asian and African nations, men resort to vindicate their false pride by engaging in the misadventure of throwing acid so as to cause indelible scars to disfigure and maim their targets and enjoys sadistic pleasure. ${ }^{2223}$

\section{E. Gang Based Disputes}

Besides the aforesaid instances of acid attack gang-based acid attacks are mainly seen in the England $^{24}$ and Indonesia ${ }^{25}$ which is a result of gang rivalry and gang-based crimes and the victims are mainly male members being a departure from the conventional crime of victims being women. The motive for the attacks is humiliating the rival gang members and it is mainly intended not to kill but intimidating the rivals by causing corrosive injuries. ${ }^{26}$ The victims would have to bear the stigma of being attacked on account of disfigurement which would isolate victims from the society. ${ }^{2728}$

\section{F. Politically Motivated Problems}

Factional rivalry among the rank and file of political parties would also lead to acid attack. In so many countries the political structure is highly volatile where rivals would involve in vendetta as political power means opportunities for corruption of public funds thereby creating illegal wealth, hence liquidating the rivals is sought for the political stability.

\section{G. Business Rivalry}

There being reasons galore for to resort to acid attack and another distinct reason is cut-throat competition in business as it is a form of business without any ethics wherein either business partners due to vendetta or rival business consortiums indulge in liquidating the opponents by targeting their rivals using this corrosive liquid. It has been noted by the Law Commission of

\footnotetext{
${ }^{22}$ Retrieved from: https://timesofindia.indiatimes.com/city/indore/Acid-attack-on-woman-for-refusingsexual-favour/articleshow/26488801.cms (Last accessed on 13th January 2022 at 20.10hrs)

${ }^{23}$ Retrieved from: http://respectwomen.co.in/acid-attack-on-woman-for-refusing-sexual-favour/ (Last accessed on 15th January 2022 at $19.54 \mathrm{hrs}$ )

${ }^{24}$ https://www.npr.org/sections/parallels/2017/08/06/541209398/acid-attacks-on-the-rise-in-the-u-k (Last accessed on 13 th January 2022 at $20.12 \mathrm{hrs}$ )

${ }^{25}$ https://www.aljazeera.com/features/2013/10/28/acid-attacks-intensify-indonesia-gang-fights (Last accessed on 13th January 2022 at $20.14 \mathrm{hrs}$ )

${ }^{26}$ Retrieved from: https://www.bbc.com/news/uk-24835910 (Last accessed on 13th January 2022 at 20.17hrs)

${ }^{27}$ Retrieved from: https://www.thesun.co.uk/news/4016850/acid-attacks-uk-london-statistics-westbournegrove/ (Last accessed on 13th January 2022 at 20.19hrs)

${ }^{28}$ Retrieved from: https://theconversation.com/acid-attacks-are-on-the-rise-and-toxic-masculinity-is-thecause-82115 (Last accessed on 13th January 2022 at 20.25hrs)
} 
India that such events are not uncommon in India. ${ }^{29}$ This modality of unhealthy rivalry needs to be addressed by deterrent punishments as well as by enlightenment drive. ${ }^{30}$

\section{H. Land Disputes}

Land disputes like India, Bangladesh and other South Asian countries were in the main avocation is agriculture, possession of land is an important factor for wealth. ${ }^{31}$ Establishing dominion over agriculture lands becomes inevitable for cultivation, hence by dubious methods citizens individually and groups indulge in land grabbing and land mafia also stretches their tentacles to control farms and even non-agricultural lands which could be utilized for industrialization. Thus, to frighten the opponents and rivals corrosive acid is used which will scare away. ${ }^{3233}$

\section{JUDICIAL INTERPRETATION OF ACID ATTACK REGARDING MEN IN INDIA SHAHABUDDIN DOUBLE MURDER CASE ${ }^{34}$}

In Siwan district of Bihar Mohammed Shahabuddin a local don and strong man decided to take revenge owing to land dispute with a businessman named Chandkeshwar Prasad. Mohammed Shahabuddin with the aid of his gang members kidnapped the sons of Chandkeshwar Prasad namely Satish and Girish with the intention of killing them. These both brothers were bathed in acid. This incident occurred in the year 2004 where Shahabuddin and his henchmen splashed acid and brutally killed both the brothers. They were sentenced to life imprisonment. The trial court held that Mohammed Shahabuddin and his men Rajkumar Sah, Arif Hussain and Sheikh Aslam guilty under section $302^{35}, 364 \mathrm{~A}, 201$ and $120 \mathrm{~B}^{36}$ of Indian Penal Code. ${ }^{37}$

\footnotetext{
${ }^{29}$ Retrieved from: https://lawcommissionofindia.nic.in/reports/report226.pdf (Last accessed on 13th January 2022 at $20.31 \mathrm{hrs})$

${ }^{30}$ Retrieved from: https://timesofindia.indiatimes.com/city/bhubaneswar/Acid-attack-on-business-rival-incity/articleshow/54160897.cms (Last accessed on 13th January 2022 at $20.32 \mathrm{hrs}$ )

${ }^{31}$ Retrieved from: https://indianexpress.com/article/india/punjab-nine-women-injured-in-acid-attack-overland-dispute-4446007/ (Last accessed on 13th January 2022 at 20.32hrs)

${ }^{32}$ Retrieved from: https://www.news18.com/news/india/20-injured-in-acid-attack-in-bihars-saran-districtfollowing-heated-argument-over-land-dispute-

3106565.html\#: :text=An\%20acid\%20attack\%20in\%20Bihar's,battling\%20for\%20life\%20in\%20hospital.\&text= During\%20this\%2C\%20some\%20supporters\%20of,bottles\%20on\%20the\%20other\%20group. (Last accessed on 3th January 2022 at $20.35 \mathrm{hrs})$

${ }^{33}$ Retrieved from: https://www.hindustantimes.com/india-news/11-people-injured-in-bihar-acid-attack-overland-dispute/story-3MSeFBUBggkZ2Em33e8eoO.html (Last accessed on 13th January 2022 at 20.35hrs)

${ }^{34}$ Criminal Appeal (DB) No.73 of 2016 OG Patna High Court.

35 The Indian Penal Code, 1860 (Act 45 of 1860), sec: 302- Punishment for murder. - Whoever commits murder shall be punished with death, or [imprisonment for life], and shall also be liable to fine.

${ }^{36}$ The Indian Penal Code, 1860 (Act 45 of 1860), sec.120B- Punishment of criminal conspiracy. -

(1) Whoever is a party to a criminal conspiracy to commit an offence punishable with death, 2[imprisonment for life] or rigorous imprisonment for a term of two years or upwards, shall, where no express provision is made in this Code for the punishment of such a conspiracy, be punished in the same manner as if he had abetted such offence.

(2) Whoever is a party to a criminal conspiracy other than a criminal conspiracy to commit an offence punishable as aforesaid shall be punished with imprisonment of either description for a term not exceeding six months, or with fine or with both.

${ }^{37}$ Retrieved from: Siwan acid attack case: Patna HC upholds ex-RJD MP Shahabuddin's life term (asianage.com) (Last accessed on 22nd January 2022 at 10.35hrs)
} 
The motive of the incident which occurred on 16-08-2004 was that Chandkeshwar Prasad denied to give mafia don Mohammed Shahabuddin the demanded extortion amount which provoked the hooligan to mercilessly commit the crime. During the trial of the case when the third son of Chandkeshwar Prasad was supposed to submit his evidence as witness in the court he was shot dead. The trail courts judgement was upheld by the High Court of Patna. ${ }^{38}$ This case is an acid attack case which was committed by the perpetrator with a motive of revenge.

\section{BHAGALPUR BLINDING CASE ${ }^{39}$}

The most notorious incidents of blinding human beings by men in police robes occurred during 1978 and the 1980 in the state of Bihar in India. The police blinded nearly 33 individuals who were accused of petty offenses and were under trial by pouring acid into their eyes. This is the infamous Bhagalpur blinding incident which shook India. This case Referred through the writ petition initiated by the undertrials under Article $32^{40}$ of the Indian Constitution as the undertrials were undergoing trial, and while in police custody they were blinded by the police force, being an official act the victim's complaint of violation of fundamental rights guaranteed under Article $21^{41}$ and claiming that this state has to pay compensation to the victims. There the question arose whether this state was liable to pay compensation. It was the contented-on behalf of the victims that the state was liable as the police officers were discharging official duty and when deprivation of personal Liberty acres the state was liable. Further the trial held without offering Legal Aid to indigent accused, such trial would be vitiated and will be set aside Providing free legal service to the poor and needy is the element of fair and just procedure. $^{4243}$

\section{MASTER ADITYA RAJ CASE ${ }^{44}$}

Minor aged two and half years sustained acid burns on 13-12-2006. The boy was playing in the street around 6pm was kidnapped so his mother lodged an FIR no. 1235/2016 dated 14-122016 under sec 364 IPC $^{45}$. the child was recovered from a public dust bin by a truck driver. The child was taken to New Delhi's Safdarjung Hospital as he sustained acid burns where he was treated but later, he was shifted to Medanta hospital. The accused was arrested later and it was found that he committed the crime on the child because his mother turned down sexual

\footnotetext{
${ }^{38}$ Retrieved from: Siwan acid attack case: Patna High Court upholds life sentence of Mohammad Shahabuddin | India News, The Indian Express (Last accessed on 13th January 2022 at 20.35hrs)

${ }^{39} 1981$ SCR (2) 408, 1981 SCC (1) 627

40 The Constitution of India, Art.32-Remedies for enforcement of rights

${ }^{41}$ The Constitution of India, Art.21- Protection of life and personal liberty No person shall be deprived of his life or personal liberty except according to procedure established by law.

${ }^{42}$ Retrieved from: The Bhagalpur Blinding Case - Lords of Law (Last accessed on 18th January 2022 at 17. 30hrs)

${ }^{43}$ Retrieved from : Khatri and Ors. vs. State of Bihar (The Bhagalpur Blinding case) - (indianlegalsolution.com) (Last accessed on 18th January 2022 at 17. 30hrs)

${ }^{44}$ CWP No. 2923 of 2017 (O and M) of Punjab and Haryana High Court.

45 The Indian Penal Code, 1860 (Act 45 of 1860), s.364- Kidnapping or abducting in order to murder.
} 
advances. The man had an evil eye on the child's mother which when denied resulted in this acid attack as part of revenge. ${ }^{46}$

\section{CONCLUSION}

There is a universal perception that women alone are acid attack victims and the men are perpetrators, but the analysis of data discloses that the said trend is being scuttled as more and more women as well as men turn to be perpetrators and about thirty to forty percent of victims occupies the men folk and in case of men being the perpetrators along with unrequited love, personal vendetta, land disputes, gang based disputes etc takes the major chunk on the other hand almost all of the woman perpetrators resort to this heinous crime for the reason of spurned love. Requisite attention of authorities concerned is not bestowed on men victims. Thereby compensation is seldom granted to them as the old concept of women victims rules the roost. Therefore, timely attention is needed to resolve this issue of "reverse gender discrimination".

\section{SUGGESTIONS}

1. Under the aegis of Ministry of Child and Women Development, the government of India has devised scheme namely 'Sakhi' which is One Stop Centre which has centers across the states and Union Territories and function to help women and child victims. The One Stop Centers shall provide success to the victims but it is only meant to be women victims as its name indicates but such centers are the need of the hour to provide relief to men as well as at present, they are left high and dry. This alone would address the issue of the skewed ratio of bestowing benefits with discrimination.

2. Another aspect which would provide more teeth to the provisions of law which renders the availability of corrosive acid unhindered is the condition that the sellers of acid shall hold a valid license to sell acid and on the other hand the buyer need not hold license to buy, possess, carry, transit, transport acid, which renders the governmental restrictions otiose as everyone desirous of the corrosive substance can handle the same as he is qualified to possess it. Here it is worthwhile to note that the arms, explosive substances etc., requires license to possess the same in any quantity and not only the vendor but the vendee also shall possess license to possess the material which makes the free transit of materials difficult. Hence, the government has to provide effective remedial amendments to the provisions by additional restrictions, to make the availability of the substance in the restricted manner and less availability corresponds to less usage of the same for oppression.

\footnotetext{
${ }^{46}$ Retrieved from: https://www.thehindu.com/news/cities/Delhi/court-convicts-man-who-threw-acid-at-twoyear-old-boy/article25023158.ece (Last accessed on 18th January 2022 at 17. 30hrs)
} 